\title{
Individual Blockholder's Influence on Accounting Quality: Evidence from Korea
}

\author{
Sang-Giun YIM ${ }^{1}$
}

Received: September 01, 2019 Revised: November 01, 2019 Accepted: November 15, 2019

\begin{abstract}
This study investigates the influence of individual blockholder on accounting quality. Prior studies investigating Korean blockholders' influence focus on the influence of controlling shareholders or institutional investors; however, they rarely examine individual blockholders' influence. This paper investigates how individual blockholders in Korean stock markets affect accounting quality of firms listed in Korean Stock Exchange. I analyze individual blockholders' influence on proxies of accounting quality using multivariate regression with hand-collected individual blockholder data. Korean law requires public firms to disclose the list of shareholders having no less than 5\% of ownership. From the list of blockholders, individuals who have no explicit personal relation with controlling shareholders were classified as individual blockholders. My empirical results show that firms having individual blockholder(s) use more income-decreasing accruals than those having no individual blockholder. Furthermore, accounting information of firms having individual blockholders(s) is more conservative than that of firms having no individual blockholders. However, the presence of individual blockholder increases the tendency of loss avoidance and earnings management using overproduction and reduction of discretionary expenditure. This paper contributes to the literature by presenting the first evidence of the monitoring role of an individual blockholder on financial reporting of firms listed in the Korean stock markets.
\end{abstract}

Keywords : Individual Blockholder, Accounting Quality, Accruals, Conservatism, Real Activities Manipulation

JEL Classification Code : G32, G34, M41

\section{Introduction}

Several studies have investigated blockholders' corporate governance role. Especially, Korean studies in this line mainly focus on blockholders, such as controlling shareholder or institutional investors. However, these studies have not focused on individual blockholders in Korean markets because they have little influence on firm operations. Individual blockholders have legal rights to monitor accounting records; thus, they could be a governance mechanism of financial reporting. To my best knowledge, no study has examined individual shareholders' monitoring

1 First Author and Corresponding Author, Assistant Professor, Faculty of School of Accounting and Finance, Kookmin University, Republic of Korea. [77, Jeongneung-ro, Seongbuk-gu, Seoul 02707, Republic of Korea] Email: yimsg@kookmin.ac.kr

(c) Copyright: Korean Distribution Science Association (KODISA)

This is an Open Access article distributed under the terms of the Creative Commons Attribution Non-Commercial License (http://Creativecommons.org/licenses/by-nc/4.0/) which permits unrestricted noncommercial use, distribution, and reproduction in any medium, provided the original work is properly cited. of financial reporting. By examining Korean individual blockholders' influence on accounting quality, this study fills the void in the literature.

Concentrated ownership is common in Asia, including Korea (Claessens, Djankov, \& Lang, 2000). In Asian firms, the controlling shareholder frequently takes the executive managerial position. For example, the real controller of Samsung Electronics, Jae-yong Lee, is the son of Kun-hee Lee who is the controlling shareholder of the firm. Hence, ownership and control are not separated. Therefore, in Asian countries except China where most Chinese firms are stateowned firms (Vijayakumaran \& Vijayakumaran 2019), the agency problem occurs between the controlling shareholder and non-controlling ones (Baek, Kang, \& Lee, 2006; Lee, 2018). Hence, I focus on corporate governance to monitor controlling shareholder.

Studies on Korean markets have focused on controlling shareholders (Baek, Kang, \& Lee, 2006); however, noncontrolling blockholders have not been investigated much. Especially, individual blockholders are rarely examined in 
corporate governance literature because their ownership is comparatively small.

Although their ownership is small, individual blockholders have monitoring power. Korea law authorizes shareholders having no less than $3 \%$ ownership to examine accounting records and to require shareholders' meeting. These rights make individual blockholder a corporate governance mechanism.

However, legal right cannot completely remove limitations from small ownership. Korean firms' controlling shareholders are well-entrenched; thus, individual blockholders cannot penalize them by voting power. Moreover, individual blockholders do not have full access to private information, which limits individual blockholders' monitoring. The individual blockholder's monitoring role has both enhancing factors and constraints; therefore, this monitoring role is an empirical question.

I focus on individual blockholders' influence on accounting quality. Individual blockholders cannot fully access internal information; hence, they would rely on accounting information. Therefore, individual blockholders' monitoring and disciplinary actions react to accounting information, which would affect controlling shareholders' accounting policy.

This could improve accounting quality because lowquality information would incur individual blockholders' activism. The use of accruals is less aggressive, and accounting conservatism would be enhanced in individual blockholders' presence. Conversely, individual blockholders' presence could deteriorate or degrade accounting quality. Since the contents of financial reporting could cause individual blockholders' disciplinary actions, for example, lawsuits, or blockholders' disposal of shares, controlling shareholder would adjust contents of accounting information to avoid shareholders' activism. As accruals management becomes harder, the use of real activities manipulation would increase. Moreover, the reporting loss would be avoidance because it could trigger shareholder activism.

To test these conjectures, I use firm-year observations of firms listed in the Korean Stock Exchange (KSE) from 2000 to 2017. Individual blockholder data were hand-collected. Korean listed firms have to disclose shareholders having no less than 5\% ownership, which this study defines as blockholders. I require that individual blockholders do not have direct connection with controlling shareholder because independence is the key to the monitoring role of individual blockholders. Current or ex-executive managers are excluded because they are related to the controlling shareholder. Thus, they are not independent. Moreover, to confirm independence, I manually investigated the relation between individual blockholder and the controlling shareholders using publicly available sources.

Empirical results for individual blockholders are twofold. The results show that individual blockholder's presence enhances accounting quality by encouraging the use of income-decreasing accruals and increasing accounting conservatism. However, individual blockholder's presence increases real activities manipulation and loss avoidance, which reduces accounting quality. In sum, individual blockholders provide limited monitoring of financial reporting.

This study has several contributions to the literature. First, to my best knowledge, this study is the first study that examines individual blockholder's monitoring of financial reporting in Korean markets. Several studies have investigated the effect of controlling shareholders or institutional investors on financial reporting. However, no study investigated the influence of individual blockholders on financial reporting using Korean data.

Second, this study provides empirical evidence of Korean individual blockholders' corporate governance role. Dou, Hope, Thomas, and Zou (2016) report that individual blockholders improve accounting quality using US data. Unlike US firms, Korean firms generally have wellentrenched controlling shareholders. In addition, investor protection of Korea is weaker than that of the US (La Porta, Lopez-de-Silanes, Shleifer, \& Vishny, 2000). This study shows that, despite these restrictions, Korean individual blockholders play a monitoring role.

Third, this study suggests that the conflict of interest among blockholders could cause an adverse result of blockholders' monitoring. The result of this study shows individual blockholder's presence enhances loss avoidance and real activities manipulation. These adverse effects indicate limitations in an individual blockholder's role as a corporate governance mechanism.

The rest of this paper proceeds as follows. Section 2 summarizes literature and institutional background. Section 3 develops hypotheses. Section 4 presents the empirical design and sample selection. Section 5 documents the empirical results, and Section 6 concludes.

\section{Literature Review and Institutional Background}

\subsection{Corporate Governance by Blockholders}

Shleifer and Vishny (1997) suggest that blockholders can be a corporate governance mechanism because blockholders have both motivation and tools to monitor insiders, which come from blockholders' large ownership. Several tools can be utilized to discipline controlling shareholder. In several countries, the law provides several rights to investors to discipline managers or controlling shareholders (La Porta, Lopez-de-Silanes, Shleifer, \& Vishny, 2000). Disposal of shares can be a disciplinary tool because blockholders' disposal could warn market participants that the firm value would decrease, which is a threat to controlling shareholders (Edmans, 2014).

Prior studies that investigated the US markets report evidence supporting blockholders' corporate governance role (Agrawal \& Chadha, 2005; Farber, 2005; Larcker, Richardson, \& Tuna, 2007). However, in Korean study, 
blockholders' corporate governance role has not been investigated much because the focus of research is mainly on controlling shareholders. In Korean firms, agency problem mainly occurs between strongly entrenched controlling shareholder who takes executive managerial positions and the other shareholders (Claessens, Djankov, \& Lang, 2000). Hence, controlling shareholders' agency problem has been a topic of interest (Baek, Kang, \& Lee, 2006). However, the other types of blockholders were not a popular research subject in Korean literature. Moreover, among several types, individual blockholders are the least influential because of comparatively small ownership. Considering the power of controlling shareholders, individual blockholders' role as a corporate governance mechanism would be limited in Korea. This may be the reason that individual blockholders' influence has not received much attention.

\subsection{Individual Blockholders}

Due to individual blockholders' relatively small ownership, they can hardly discipline the controlling shareholder using their voting rights. However, individual blockholders' legal rights and share disposal could give disciplinary power to individual blockholders.

Dou, Hope, Thomas, and Zou (2016) examine how individual blockholder is related to earnings quality using the US data and find that earnings quality is improved by individual blockholders. US public firms generally do not have a controlling shareholder. Also, the US markets have strong investor protection. These two conditions could enhance the effectiveness of individual blockholders' monitoring. Therefore, the findings of Dou, Hope, Thomas, and Zou (2016) cannot be extrapolated to the Korean markets because of the well-entrenched controlling shareholder and weak investor protection.

\subsection{Blockholder's Legal Right in Korea}

Korean Commercial Act authorizes blockholders legal rights. Especially, the Commercial Act gives blockholders having no less than $3 \%$ of ownership the right to inspect accounting record (Commercial Act Article 466), to "request the court to remove the director for inappropriate activities (Commercial Act Article 385)," to "request convocation of an extraordinary general meeting of shareholders (Commercial Act Article 366)," to "request court to appoint an inspector to inspect the business affairs of the company and the status of its assets (Commercial Act Article 467)," and so on. These rights enable blockholders to play a corporate governance role.

Shleifer and Vishny (1997) suggest ownership around 10\% to $20 \%$ as a criterion to be classified as a blockholder. Compared with this threshold, $3 \%$ of ownership is relatively small. However, legal rights support that blockholders having $3 \%$ of ownership could provide effective monitoring.
Korean law requires listed firms to disclose the list of blockholders that have no less than $5 \%$ of ownership in the annual report, which enables researchers to identify blockholders specifically from public data. However, the disclosure requirement does not necessitate the relation between controlling shareholder and blockholders to be indicated. Furthermore, despite their legal rights, shareholders having more than $3 \%$ but less than $5 \%$ of ownership are not disclosed unless they are a family member of controlling shareholders.

\section{Hypothesis Development}

An individual blockholder has the incentive to monitor controlling shareholder to protect his/her property (Shleifer \& Vishny, 1997). Using the rights that are authorized by Korean Law, a blockholder can monitor and discipline controlling shareholder. Furthermore, by using threat of exit, blockholders can suppress controlling shareholder's selfinterested transactions even without legal rights (Edmans, 2014). In sum, non-controlling blockholders in the Korean capital markets can play as a corporate governance mechanism and alleviate controlling shareholders' selfinterested decisions.

Although equal legal rights are given, blockholders' monitoring power and their influence vary by their characteristics (Bushee, 1998; Dou et al., 2016). Activism through the market mechanism depends on the ownership; hence, blockholders having small ownership would perform limited monitoring. The descriptive statistics of in Table 1 shows that individual shareholders' ownership is smaller than that of institutional investors. Therefore, individual blockholders who have comparatively small ownership than the other types of blockholders can have a restricted monitoring power.

In addition, available resources also limit the effectiveness of individual blockholders' monitoring. Institutional blockholders can use more resources for monitoring than individual blockholders. For example, unless an individual blockholder also works in the same industry as his/her investee firm, the individual blockholder's access to the information in the product markets could be limited. However, institutional blockholders, especially financial institutions, can easily gain access to the product market that their investee companies operate through different channels. This limitation in the available resource would constrain individual blockholders' monitoring ability. Furthermore, the legal process, which is crucial in monitoring (La Porta, Lopez-de-Silanes, Shleifer, \& Vishny, 2000), is generally an affordable option to an institutional blockholders, but not to an individual blockholders, because of the financial burden.

Controlling shareholders have incentive to overstate earnings. The overstated earnings increase the stick price higher than its real value, which contributes to the controlling shareholders' economic benefit in at least two 
ways. First, the high stock price attracts investors, which facilitates capital raise and reduces the likelihood of financial constraint. A good example is Samsung Electronics. Controlling shareholder family has been indicted or investigated by the Public Prosecutors Office; however, credit ratings of Samsung Electronics are very high, which implies that high performance facilitates debt financing. Second, overstated earnings could reduce shareholder's activism, including hostile takeover. Although Korean controlling shareholders are deeply entrenched, their direct ownership is generally low (Claessens, Djankov, \& Lang, 2000). Thus, hostile takeover is a serious threat to most Korean controlling shareholders. For example, in 2005, Sovereign, a hedge fund, attempted to take control over SK C\&C. During its takeover attempt against SK C\&C., Sovereign claimed that the controlling shareholder was not maximizing the shareholder value, which shows that reporting high performance could mitigate the risk of hostile takeover attempt.

The overstating of earnings benefits the controlling shareholder but destroys the other investor's wealth (Healy \& Wahlen, 1999). Therefore, regarding financial reporting, the role of corporate governance is to reduce the overstating of income. Using accruals, a controlling shareholder can overstate earnings at low costs. Changes in assumptions or accounting models can change accruals. Therefore, an individual blockholder would monitor whether accruals are estimated optimistically to prevent overstating of earnings. Korean law authorizes blockholders the rights to inspect investee firm's accounting book. Considering this, controlling shareholders of the firms having individual shareholder are likely to reduce optimism in accounting. Especially, the incentive to overstate earnings is stronger when accruals reduce the financial outcome.

Based on the conjecture above, the following hypothesis is derived:

H1: The presence of an individual blockholder reduces the use of income-increasing accruals.

Outsiders require asymmetric verifiability, that is, accounting conservatism, in recognizing good and bad news (Watts, 2003). Accounting conservatism alleviates investors' adverse selection. Individual blockholders have legal rights to force the controlling shareholder to enhance accounting conservatism; consequently, accounting conservatism would be enhanced in the presence of an individual blockholder. Therefore, the second hypothesis is set:
H2: The presence of an individual blockholder enhances asymmetric accounting conservatism.

Due to individual blockholders' limited monitoring ability, individual blockholder's presence could degrade some aspects of accounting quality. Real activities are comparatively harder to detect than accruals management for outsiders unless they have private information about the internal operation. Blockholder's legal rights do not resolve the information asymmetry regarding operating decisions; thus, individual blockholders cannot fully monitor real activities manipulation. Therefore, as the costs of accruals management increases in individual blockholder's presence, real activities manipulation can be a tool to overstate earnings (Cohen, Dey, \& Lys, 2008). Hence, under the monitoring of an individual blockholder, real activities manipulation is likely to be utilized to overstate performance. Therefore, the third hypothesis is derived:

H3: The presence of an individual blockholder increases real activities manipulation.

Loss reporting incurs several capital markets or contractual consequences. Therefore, insiders have the incentive to avoid reporting loss (Burgstahler \& Dichev, 1997). Especially in a firm having several blockholders, the risk of loss reporting is larger because loss could trigger blockholders' activism. Thus, insiders of a firm with an individual blockholder would avoid loss reporting. Therefore, the fourth hypothesis is as follows:

H4: The presence of an individual blockholder enhances the tendency of loss avoidance.

\section{Empirical Design and Sample}

\subsection{Empirical Model}

The performance-matched modified Jones model was used to estimate discretionary accruals (Kothari, Leone, \& Wasley, 2005). Equation (1) was estimated, then the residuals of the model were defined as performancematched discretionary accruals (DACC). Outliers of continuous variables were truncated at $1 \%$ level. In the estimation, I excluded firm-year having less than 10 observations from estimation. Variable definitions are presented at the end of this section.

$$
\frac{\text { Accruals }_{t}}{\text { Assets }_{t-1}}=\alpha+\beta_{1} \frac{1}{\text { Assets }_{t-1}}+\beta_{2} \frac{\left(\operatorname{Sales}_{t}-\Delta \mathrm{AR}_{t}\right)}{\text { Assets }_{t-1}}+\beta_{3} \frac{P P E_{t}}{\text { Assets }_{t-1}}+\beta_{4} \text { ROA }_{t}+\varepsilon_{t} \cdots \cdots \cdots \cdots
$$

I measured accounting conservatism using the method of Khan and Watts (2009). Conservatism measure was estimated by two-step process. First, equation (2) was estimated by year. Outliers of continuous variables were truncated at $1 \%$ level. Then, using the estimated coefficients of equation (2), I calculated the CSCORE using equation (3). 


$$
\begin{gathered}
\frac{\text { Earnings }_{t}}{M V E_{t-1}}=\beta_{0}+\beta_{1} D_{t}+R_{t}\left(\mu_{1}+\mu_{2} S I Z E_{t}+\mu_{3} M T B_{t}+\mu_{4} L E V_{-} M V_{t}\right)+D_{t} R_{t}\left(\lambda_{1}+\lambda_{2} S I Z E_{t}+\lambda_{3} M T B_{t}+\lambda_{4} L E V_{-} M V_{t}\right) \\
+\left(\delta_{1} S I Z E_{t}+\delta_{2} M T B_{t}+\delta_{3} L E V_{-} M V_{t}+\delta_{4} D_{t} S I Z E_{t}+\delta_{2} D_{t} M T B_{t}+\delta_{3} D_{t} L E V_{-} M V_{t}\right)+\varepsilon \cdots \cdots(2) \\
\operatorname{CSCORE}=\hat{\lambda}_{1}+\hat{\lambda}_{2} S I Z E_{t}+\hat{\lambda}_{3} M T B_{t}+\hat{\lambda}_{4} L E V_{-} M B E_{t} \cdots \cdots \cdots \cdots(3)
\end{gathered}
$$

CSCORE is the proxy of conservatism estimated by firm-year and is increased in accounting conservatism.

Real activities manipulation was measured following Roychowdhury (2006). First, equations (4) to (6) were estimated by industry-year. Then, the residuals are defined as abnormal cash flows (ABCFO), abnormal production (ABPROD), and abnormal discretionary expenses (ABDISX). Outliers of continuous variables were truncated at $1 \%$ level. I required the firm-year to have at least 10 industry-year observations.

$$
\begin{gathered}
\mathrm{CFO}_{t}=\beta_{1} \frac{1}{\text { Assets }_{t-1}}+\beta_{2} \frac{\text { Sales }_{t}}{\text { Assets }_{t-1}}+\beta_{3} \frac{\Delta \text { Sales }_{t}}{\text { Assets }_{t-1}}+\varepsilon_{t} \cdots \cdots \cdots \cdots(4) \\
\text { PROD }_{t}=\beta_{1} \frac{1}{\text { Assets }_{t-1}}+\beta_{2} \frac{\text { Sales }_{t}}{\text { Assets }_{t-1}}+\beta_{3} \frac{\Delta \text { Sales }_{t}}{\text { Assets }_{t-1}}+\beta_{4} \frac{\Delta \text { Sales }_{t-1}}{\text { Assets }_{t-1}}+\varepsilon_{t} \cdots \cdots \cdots \cdots \\
\operatorname{DISX}_{t}=\beta_{1} \frac{1}{\text { Assets }_{t-1}}+\beta_{2} \frac{\text { Sales }_{t}}{\text { Assets }_{t-1}}+\varepsilon_{t} \cdots \cdots \cdots \cdots(6)
\end{gathered}
$$

ABPROD is positively related to overstated earnings. However, $\mathrm{ABCFO}$ is negatively related to earning overstatement because abnormal sales, for example, channel stuffing and abnormal price discount, increase revenue but decrease ABCFO. Reduction of discretionary expense, ABDISX is also related to earning overstatement.
Finally, the proxy of loss avoidance was measured based on the work of Burgstahler and Dichev (1997). If net income is positive and less than $1 \%$ of market capital, then LAVOID is unity, and 0 otherwise.

To test our hypothesis, the following multivariate regression model was estimated:

$$
\text { (Dep.Var) }=\alpha+\beta_{1} D U M M Y_{I N D I V}+\beta_{2} \mathrm{OWN}_{\mathrm{CTRL}}+\beta_{3} \mathrm{OWN}_{\mathrm{FOR}}+\text { CONTROLS }+\mathrm{YEAR}_{\mathrm{dummy}}+\mathrm{IND}_{\text {dummy }}+\varepsilon_{t} \cdots(7)
$$

The dependent variable (Dep.Var) is chosen according to test hypothesis. DUMMY INDIV is a dummy variable indicating that the firm has at least one individual blockholder in the year. The controlling shareholder has a substantial influence on the quality of financial reporting; therefore, controlling shareholder's ownership $\left(\mathrm{OWN}_{\mathrm{CTRL}}\right)$ is controlled (Salehi, Abedini, \& Bahrani, 2014; Salehi \& Asgari, 2013). Additionally, foreign shareholders' ownership $\left(\mathrm{OWN}_{\mathrm{FOR}}\right)$ is controlled because several studies show that foreign investors monitor firm activities successfully in the Korean capital market (Han, Kang, \& Shin, 2016; Kang \& Kim, 2014). To exclude the influence from the unknown year- or industry-specific factors, year and industry fixed effects are controlled.

The sets of other control variables (CONTROLS) vary according to the dependent variable. DACC model controls the size, operating cash flows, leverage, market-to-book value ratio of equity, the changes in sales, volatility of sales, loss reporting, lagged accruals, and the dummy variable indicating whether the firm is audited by big- $\mathrm{N}$ auditor.
CSCORE model controls volatility of daily stock return, investment cycle, firm age, and liquidity (Khan \& Watts, 2009).

The regression models for real activities manipulations control firm size, leverage, current and lagged return on assets, market-to-book value ratio of equity, and lagged accruals.

For the model of loss avoidance, the following variables are controlled: market-to-book value ratio of equity, size, operating cash flows, return on assets, buy-and-hold stock return for the year, the dummy variable indicating whether the firm is audited by big-N auditor, and the dummy variable indicating whether or not the firm raises capital.

In the estimation of all the main regression model, outliers of continuous variable were trimmed at $1 \%$. To control within-firm autocorrelation, standard errors of coefficients were adjusted by firm-level clustering (Petersen, 2009).

These are the variable definitions:

DUMMY $_{\text {INDIV }}=$ Indicator variable for the presence of independent individual blockholder 


\begin{tabular}{|c|c|c|c|}
\hline $\operatorname{DUMMY}_{10 \%}$ & $\begin{aligned} &= \text { Indicator variable for the presence of } \\
& \text { independent individual blockholder }\end{aligned}$ & LIQUIDITY & $\begin{aligned}= & \text { Average weekly trading volume } \\
& \text { deflated by average issued stock }\end{aligned}$ \\
\hline \multirow[b]{2}{*}{ DUMMY $_{15 \%}$} & having no less than $10 \%$ ownership & LOSS & $=$ Indicator variable for loss from \\
\hline & $\begin{array}{c}=\text { Indicator variable for the presence of } \\
\text { independent individual blockholder } \\
\text { having no less than } 15 \% \text { ownership }\end{array}$ & МTB & $\begin{array}{l}\text { ongoing operations } \\
=\begin{array}{l}\text { Market value of equity divided by } \\
\text { book value of equity }\end{array}\end{array}$ \\
\hline \multirow[t]{2}{*}{ DUMMY $_{20 \%}$} & $=$ Indicator variable for the presence of & MVE & $=$ Market value of equity \\
\hline & $\begin{array}{l}\text { independent individual blockholder } \\
\text { having no less than } 20 \% \text { ownership }\end{array}$ & PPE & $=$ Depreciable tangible assets \\
\hline \multirow[t]{2}{*}{ NUMBER $_{\text {INDIV }}$} & $\begin{aligned} &= \text { The number of independent } \\
& \text { individual blockholders }\end{aligned}$ & PROD & $\begin{array}{l}=\text { The sum of cost of goods sold and the } \\
\text { changes in inventory deflated by }\end{array}$ \\
\hline & $\begin{aligned} &= \text { The sum of the independent } \\
& \text { individual blockholders' ownership }\end{aligned}$ & RETVOL & $\begin{aligned} & \text { lagged total assets. } \\
= & \text { Standard deviation of the daily stock }\end{aligned}$ \\
\hline $\mathrm{OWN}_{\mathrm{CTRL}}$ & $=\begin{array}{l}\text { The ownership of controlling } \\
\text { shareholder family }\end{array}$ & ROA & $\begin{aligned} & \text { return for the year } \\
= & \text { Income from ongoing operation }\end{aligned}$ \\
\hline $\mathrm{OWN}_{\mathrm{FOR}}$ & $\begin{array}{l}=\begin{array}{l}\text { The ownership of foreign } \\
\text { shareholders. }\end{array}\end{array}$ & LAG_ROA & $\begin{aligned} & \text { deflated by lagged total assets } \\
= & \text { Lagged ROA }\end{aligned}$ \\
\hline $\mathrm{ABCFO}$ & $=$ Residuals of equation (4) & Sales & $=$ Sales revenue \\
\hline ABPROD & $=$ Residuals of equation $(5)$ & SALES & $=$ Sales revenue deflated by lagged tota \\
\hline ABDISX & $=$ Residuals of equation $(6)$ & & \\
\hline Accruals & $=\begin{array}{c}\text { Income from ongoing operations less } \\
\text { operating cash flows }\end{array}$ & $\triangle$ SALES & $\begin{aligned}= & \text { Changes in sales of the year deflated } \\
& \text { by lagged total assets }\end{aligned}$ \\
\hline ACC & $=$ Income from ongoing operations less & SALESVOL & $\begin{array}{l}=\text { The volatility of SALES for the last } 5 \\
\text { years including current year }\end{array}$ \\
\hline & $\begin{array}{l}\text { operating cash flows deflated by } \\
\text { lagged total assets }\end{array}$ & SIZE & $\begin{array}{l}=\text { Natural } \log \text { of total assets in thousand } \\
\text { Korean won. }\end{array}$ \\
\hline LAG_ACC & $=$ Lagged ACC & YRET & $=$ Annualized buy-and-hold stock return \\
\hline
\end{tabular}

AGE $\quad=$ Number of years listed in KSE

$\triangle \mathrm{AR}=$ The changes in account receivables

Assets $\quad=$ Book value of total assets

BIGN $=$ Indicator variable for big-N auditor

$\mathrm{CFO} \quad=$ Operating cash flows deflated by lagged total assets.

CSCORE $=$ Firm-year measure of accounting conservatism, calculated by equation (3) using estimates of equation (2).

DACC $=$ Residuals of equation (1)

DISX $=$ The sum of expenses for R\&D, advertisement, selling, and administrative activities deflated by lagged total assets.

DUMMY $_{\mathrm{FIN}}=$ Indicator variable for capital raising of the year

Earnings $\quad=$ Income from ongoing operations

INVCYCLE = Depreciation expenses deflated by lagged total assets

LAVOID $=1$ if the net income is above $0 \%$ to $1 \%$ of market capitalization, and 0 otherwise.

LEV = Total liabilities deflated by lagged total assets

LEV_MV = Total liabilities deflated by lagged market value of equity

\subsection{Sample and Descriptive Statistics}

This study analyzes KSE-listed firms from 2000 to 2017. The observations that cannot calculate dependent or independent variables are excluded from the sample. Moreover, the observation is excluded if December is not the fiscal year-end. Therefore, the final sample consists of 4,224 firm-year observations.

The individual blockholder data were hand-collected from the annual report. Prior studies classify blockholders differently. Shleifer and Vishny (1997) define shareholders with $10 \%$ to $20 \%$ of ownership as blockholders. However, Dou, Hope, Thomas, and Zou (2016) classify shareholders having no less than 5\% ownership as blockholder. I use 5\% ownership as the criterion of blockholder because of data availability and legal rights given by Korean Commercial Act. Korean public firms are required to disclose a list of non-controlling shareholders that have no less than $5 \%$ of ownership. Individual blockholder data were collected based on the disclosure. The blockholders that cannot be classified as individual blockholders were manually excluded from the list of individual blockholders. Among individual blockholders, those who have a personal connection with the controlling shareholder or were the executive manager of the firm are also excluded from individual blockholders because they are not expected to monitor or discipline the controlling shareholder or insiders. All the publicly available information sources including financial statement, news 
media, and internet search are used to exclude individual shareholders that have a personal connection with controlling shareholder of the firm from the list of individual blockholders.

Table 1 presents the descriptive statistics of the final sample. The average of DUMMY INDIV shows that only 5\% of the observations have individual blockholders. This means that having independent individual blockholders is not common for firms listed in KSE. Also, the average ownership of individual blockholder is only $0.6 \%$. Compared with the ownership of controlling shareholders or foreign shareholders, individual blockholders' ownership is small.

\section{Table 1: Descriptive Statistics}

\begin{tabular}{|l|c|c|c|c|c|}
\hline \multicolumn{1}{|c|}{ Variables } & $\mathbf{N}$ & Mean & $\mathbf{Q 1}$ & Median & Q3 \\
\hline DUMMY $_{\text {INDIV }}$ & 4,224 & 0.052 & 0.000 & 0.000 & 0.000 \\
\hline NUMBER $_{\text {INDIV }}$ & 4,224 & 0.067 & 0.000 & 0.000 & 0.000 \\
\hline OWN $_{\text {INDIV }}$ & 4,224 & 0.006 & 0.000 & 0.000 & 0.000 \\
\hline OWN $_{\text {CTRL }}$ & 4,224 & 0.445 & 0.329 & 0.450 & 0.545 \\
\hline OWN $_{\text {FOR }}$ & 4,224 & 0.093 & 0.005 & 0.035 & 0.126 \\
\hline DACC & 4,224 & -0.001 & -0.031 & -0.001 & 0.030 \\
\hline ABCFO & 4,224 & 0.007 & -0.030 & 0.007 & 0.044 \\
\hline ABPROD & 4,224 & -0.002 & -0.054 & 0.003 & 0.053 \\
\hline ABDISX & 4,224 & -0.005 & -0.036 & -0.012 & 0.015 \\
\hline CSCORE & 4,224 & 0.703 & 0.142 & 0.594 & 1.134 \\
\hline LAVOID & 4,224 & 0.027 & 0.000 & 0.000 & 0.000 \\
\hline SIZE & 4,224 & 5.628 & 4.789 & 5.433 & 6.328 \\
\hline CFO & 4,224 & 0.057 & 0.019 & 0.057 & 0.096 \\
\hline LEV & 4,224 & 0.337 & 0.077 & 0.290 & 0.548 \\
\hline MTB & 4,224 & 0.789 & 0.417 & 0.636 & 0.976 \\
\hline SALES & 4,224 & 1.091 & 0.740 & 1.011 & 1.324 \\
\hline SALESVOL & 4,223 & 0.223 & 0.095 & 0.155 & 0.261 \\
\hline LOSS & 4,224 & 0.143 & 0.000 & 0.000 & 0.000 \\
\hline LAG_ACC & 4,224 & -0.015 & -0.053 & -0.017 & 0.022 \\
\hline BIGN & 4,224 & 0.633 & 0.000 & 1.000 & 1.000 \\
\hline ROA & 4,224 & 0.041 & 0.014 & 0.040 & 0.071 \\
\hline RETVOL & 4,224 & 0.028 & 0.021 & 0.026 & 0.034 \\
\hline INVCYCLE & 4,224 & 0.005 & 0.001 & 0.003 & 0.006 \\
\hline AGE & 4,224 & 20.900 & 12.000 & 20.000 & 29.000 \\
\hline LIQUIDITY & 4,224 & 0.019 & 0.002 & 0.005 & 0.011 \\
\hline DUMMY & 4,224 & 0.896 & 1.000 & 1.000 & 1.000 \\
\hline YRET & 4,224 & 0.080 & -0.158 & 0.048 & 0.299 \\
\hline
\end{tabular}

\section{Empirical Results}

\subsection{Discretionary Use of Accruals}

Table 2 shows the influence of an individual blockholder on discretionary accruals. Columns (1), (2), and (3) document the results of full sample, positive DACC subsample, and negative DACC subsample, respectively. In the full sample analysis, DACC is not significantly related to DUMMY INDIV. To investigate the influence of individual blockholder on the DACC further, I divide the sample into subsamples according to the sign of DACC. In the negative DACC subsample analysis presented in column (2), the coefficient of individual blockholder dummy variable is insignificant. However, as shown in column (3), the DUMMY $_{\text {INDIV }}$ has a negative coefficient in the negative DACC subsample. In sum, these results indicate that a firm having at least one individual blockholder uses incomedecreasing discretionary accruals more than a firm without an individual blockholder. Considering that blockholders have the rights to monitor accounting records, Table 2 supports the conjecture that aggressive accruals use would be suppressed by individual blockholders.

Table 2: Discretionary Accruals Model: Number of Individual Blockholders

\begin{tabular}{|c|c|c|c|}
\hline Variables & $\begin{array}{c}(1) \\
\text { Full sample } \\
\text { DACC }\end{array}$ & $\begin{array}{c}(2) \\
\text { DACC >0 } \\
\text { DACC }\end{array}$ & $\begin{array}{c}(3) \\
\text { DACC }<0 \\
\text { DACC }\end{array}$ \\
\hline DUMMY INDIV & $\begin{array}{l}-0.002 \\
(-0.94)\end{array}$ & $\begin{array}{l}-0.001 \\
(-0.35)\end{array}$ & $\begin{array}{l}-0.005^{*} \\
(-1.87)\end{array}$ \\
\hline$O W N_{C T R L}$ & $\begin{array}{l}0.005 \\
(1.42) \\
\end{array}$ & $\begin{array}{c}0.010^{* * *} \\
(2.82)\end{array}$ & $\begin{array}{l}0.001 \\
(0.38) \\
\end{array}$ \\
\hline $\mathrm{OWN}_{\mathrm{FOR}}$ & $\begin{array}{l}0.004 \\
(0.67)\end{array}$ & $\begin{array}{l}0.010^{*} \\
(1.88)\end{array}$ & $\begin{array}{l}-0.004 \\
(-0.68)\end{array}$ \\
\hline SIZE & $\begin{array}{c}0.002^{* \star *} \\
(2.68)\end{array}$ & $\begin{array}{l}0.000 \\
(0.18)\end{array}$ & $\begin{array}{c}0.002^{\star * *} \\
(2.99)\end{array}$ \\
\hline CFO & $\begin{array}{c}-0.724^{* * *} \\
(-69.69)\end{array}$ & $\begin{array}{c}-0.465^{\star \star *} \\
(-26.56)\end{array}$ & $\begin{array}{c}-0.487^{\star \star \star} \\
(-32.46)\end{array}$ \\
\hline LEV & $\begin{array}{l}-0.003 \\
(-1.19)\end{array}$ & $\begin{array}{l}0.001 \\
(0.53)\end{array}$ & $\begin{array}{c}-0.010^{\star \star *} \\
(-4.32)\end{array}$ \\
\hline MTB & $\begin{array}{c}0.007^{\star \star \star} \\
(4.73)\end{array}$ & $\begin{array}{c}0.006^{\star \star \star} \\
(4.49)\end{array}$ & $\begin{array}{c}0.004^{* * *} \\
(3.31)\end{array}$ \\
\hline$\triangle$ SALES & $\begin{array}{c}0.018^{\star * \star} \\
(5.82)\end{array}$ & $\begin{array}{c}0.015^{\star * *} \\
(4.34)\end{array}$ & $\begin{array}{c}0.010^{\star * *} \\
(3.01)\end{array}$ \\
\hline SALESVOL & $\begin{array}{c}0.007^{\star \star *} \\
(2.84)\end{array}$ & $\begin{array}{c}0.005^{\star *} \\
(2.19)\end{array}$ & $\begin{array}{l}0.001 \\
(0.56)\end{array}$ \\
\hline LOSS & $\begin{array}{c}-0.037^{\star * *} \\
(-19.36)\end{array}$ & $\begin{array}{c}-0.019^{\star \star *} \\
(-9.95)\end{array}$ & $\begin{array}{l}-0.031^{* \star *} \\
(-13.86)\end{array}$ \\
\hline LAG_ACC & $\begin{array}{l}-0.013 \\
(-1.48)\end{array}$ & $\begin{array}{l}-0.002 \\
(-0.24)\end{array}$ & $\begin{array}{l}-0.013 \\
(-1.24)\end{array}$ \\
\hline BIGN & $\begin{array}{l}0.000 \\
(0.33) \\
\end{array}$ & $\begin{array}{l}0.001 \\
(0.88) \\
\end{array}$ & $\begin{array}{l}0.001 \\
(0.76) \\
\end{array}$ \\
\hline Year dummy & Included & Included & Included \\
\hline Ind. dummy & Included & Included & Included \\
\hline Observations & 4,223 & 2,080 & 2,143 \\
\hline Adj. R2 & 0.667 & 0.460 & 0.503 \\
\hline
\end{tabular}

To further examine the influence of an individual blockholder, I regressed the number of individual blockholders and the sum of individual blockholders' ownership on discretionary accruals. The results are presented in panels A and B of Table 3. Consistent with Table 2, a firm uses more income-decreasing accruals as the number of individual blockholders (NUMBER INDIV) $_{\text {) }}$ increases, indicating that the individual blockholders' monitoring is strengthened in the number of individual blockholders. However, the total ownership of individual blockholders (OWN $\left.\mathrm{ONDIV}_{\mathrm{IN}}\right)$ does not have significant relation with discretionary accruals. This means that monitoring is weakened in the total ownership of individual blockholders, which seems inconsistent with previous results. By 
dissecting individual blockholders by the level of ownership, I investigate the inconsistency of the results further. The dummy variables DUMMY $_{10 \%}$, DUMMY $_{15 \%}$, and DUMMY $_{20 \%}$ indicate the presence of individual blockholder(s) having no less than $10 \%, 15 \%$, and $20 \%$ of ownership, respectively. Panel $\mathrm{C}$ of Table 3 documents the regression results. For brevity, Panel $\mathrm{C}$ reports only the results of income-decreasing accruals $($ DACC $<0)$ subsample. The indicator variable for individual blockholder having more than $15 \%$ (20\%) ownership is positively related to DACC, implying that an individual blockholder having ownership more than $15 \%$ weakens the monitoring of accounting discretion. A potential explanation is that as the ownership increases, the increased voting power of the individual blockholder allows colluding of the controlling shareholder with the large individual blockholder. The collusion reduces the motivation of monitoring, which weakens the use of income-decreasing accruals.

Table 3: Discretionary Accruals Model: Additional Models

Panel A: Number of Individual Blockholders

\begin{tabular}{|l|c|c|c|}
\hline Variables & $\begin{array}{c}(\mathbf{1}) \\
\text { Full sample } \\
\text { DACC }\end{array}$ & $\begin{array}{c}(\mathbf{2}) \\
\text { DACC }>\mathbf{0} \\
\text { DACC }\end{array}$ & $\begin{array}{c}\mathbf{( 3 )} \\
\text { DACC }<\mathbf{0} \\
\text { DACC }\end{array}$ \\
\hline NUMBER & -0.002 & -0.002 & $-0.003^{*}$ \\
& $(-1.38)$ & $(-0.87)$ & $(-1.89)$ \\
\hline OWN $_{\text {CTRL }}$ & 0.005 & $0.010^{\star * *}$ & 0.001 \\
& $(1.37)$ & $(2.76)$ & $(0.39)$ \\
\hline OWN & 0.004 & $0.010^{*}$ & -0.004 \\
& $(0.66)$ & $(1.87)$ & $(-0.69)$ \\
\hline Controls & Included & Included & Included \\
\hline Year dummy & Included & Included & Included \\
\hline Ind. dummy & Included & Included & Included \\
\hline Observations & 4,223 & 2,080 & 2,143 \\
\hline Adj. R2 & 0.667 & 0.461 & 0.503 \\
\hline
\end{tabular}

Panel B: Sum of Individual Blockholders

\begin{tabular}{|l|c|c|c|}
\hline Variables & $\begin{array}{c}(\mathbf{1}) \\
\text { Full sample } \\
\text { DACC }\end{array}$ & $\begin{array}{c}(\mathbf{2}) \\
\text { DACC }>\mathbf{0} \\
\text { DACC }\end{array}$ & $\begin{array}{c}(\mathbf{3}) \\
\text { DACC }<0 \\
\text { DACC }\end{array}$ \\
\hline OWN $_{\text {INDIV }}$ & -0.013 & -0.012 & -0.022 \\
& $(-0.80)$ & $(-0.62)$ & $(-1.17)$ \\
\hline OWN $_{\text {CTRL }}$ & 0.005 & $0.010^{* * *}$ & 0.002 \\
& $(1.42)$ & $(2.76)$ & $(0.47)$ \\
\hline OWN $_{\text {FOR }}$ & 0.004 & $0.010^{*}$ & -0.004 \\
& $(0.64)$ & $(1.85)$ & $(-0.72)$ \\
\hline Controls & Included & Included & Included \\
\hline Year dummy & Included & Included & Included \\
\hline Ind. dummy & Included & Included & Included \\
\hline Observations & 4,223 & 2,080 & 2,143 \\
\hline Adj. R2 & 0.667 & 0.460 & 0.502 \\
\hline
\end{tabular}

Panel C: Individual Blockholders with Large Ownership

\begin{tabular}{|l|c|c|c|}
\hline & $\begin{array}{c}(\mathbf{1}) \\
\text { Vull sample } \\
\text { DACC }\end{array}$ & $\begin{array}{c}(\mathbf{2}) \\
\text { DACC }>0 \\
\text { DACC }\end{array}$ & $\begin{array}{c}(\mathbf{3}) \\
\text { DACC }<0 \\
\text { DACC }\end{array}$ \\
\hline DUMMY $_{\text {INDIV }}$ & $-0.007^{* *}$ & $-0.006^{* *}$ & $-0.005^{*}$ \\
& $(-2.45)$ & $(-2.07)$ & $(-1.93)$ \\
\hline DUMMY $_{10 \%}$ & 0.007 & & \\
& $(1.11)$ & & \\
\hline DUMMY $_{15 \%}$ & & $0.014^{* * *}$ & \\
& & $(2.93)$ & \\
\hline
\end{tabular}

\begin{tabular}{|l|c|c|c|}
\hline DUMMY $_{20 \%}$ & & & $\begin{array}{c}0.010^{* \star} \\
(2.05)\end{array}$ \\
\hline OWN $_{\text {CTRL }}$ & 0.001 & 0.001 & 0.001 \\
& $(0.38)$ & $(0.34)$ & $(0.36)$ \\
\hline OWN $_{\text {FOR }}$ & -0.003 & -0.003 & -0.003 \\
& $(-0.64)$ & $(-0.64)$ & $(-0.65)$ \\
\hline Controls & Included & Included & Included \\
\hline Year dummy & Included & Included & Included \\
\hline Ind. dummy & Included & Included & Included \\
\hline Observations & 2,143 & 2,143 & 2,143 \\
\hline Adj. R2 & 0.503 & 0.503 & 0.503 \\
\hline
\end{tabular}

Firm-clustered t-values are presented in parentheses. * ${ }^{* *}$, and *** indicate statistical significance at $10 \%, 5 \%$, and $1 \%$ in a twotailed test, respectively

\subsection{Accounting Conservatism}

Table 4 presents the individual blockholder effect of accounting conservatism. Accounting conservatism, measured by the method of Khan and Watts (2009), is positively related to $\mathrm{DUMMY}_{\text {INDIV }}$, NUMBER $\mathrm{NUVID}_{\text {IN }}$, and OWN $\mathrm{N}_{\text {INDIV }}$, implying that individual blockholders enhance accounting conservatism. Individual blockholders demand conservative accounting information; hence, controlling shareholders provide conservative accounting information to mitigate the risk of blockholders' activism. These results support my hypothesis. Individual blockholders' activism incurs costs to controlling shareholders, for example, regulation authorities' supervisory actions or low valuation of the enterprise. Therefore, a controlling shareholder would avoid the costly consequences of unreliable accounting information by providing conservative accounting information (Watts, 2003).

Table 4: Accounting Conservatism

\begin{tabular}{|c|c|c|c|}
\hline Variables & $\begin{array}{c}\text { (1) } \\
\text { CSCORE }\end{array}$ & $\begin{array}{c}\text { (2) } \\
\text { CSCORE }\end{array}$ & $\begin{array}{c}\text { (3) } \\
\text { CSCORE }\end{array}$ \\
\hline DUMMYINDIV $_{\text {IN }}$ & $\begin{array}{c}0.131^{\star \star *} \\
(2.76) \\
\end{array}$ & & \\
\hline $\mathrm{NUMBER}_{\text {INDIV }}$ & & $\begin{array}{c}0.081^{* * *} \\
(2.92)\end{array}$ & \\
\hline OWN ${ }_{\text {INDIV }}$ & & & $\begin{array}{c}0.838^{\star * *} \\
(2.88)\end{array}$ \\
\hline $\mathrm{OWN}_{\mathrm{CTRL}}$ & $\begin{array}{l}0.075 \\
(0.97) \\
\end{array}$ & $\begin{array}{l}0.076 \\
(0.98)\end{array}$ & $\begin{array}{l}0.074 \\
(0.95)\end{array}$ \\
\hline OWN & $\begin{array}{c}-1.009^{* * *} \\
(-7.57) \\
\end{array}$ & $\begin{array}{c}-1.008^{\star * *} \\
(-7.50)\end{array}$ & $\begin{array}{c}-1.006^{\star * *} \\
(-7.48)\end{array}$ \\
\hline RETVOL & $\begin{array}{l}-0.417 \\
(-0.39) \\
\end{array}$ & $\begin{array}{l}-0.370 \\
(-0.35)\end{array}$ & $\begin{array}{l}-0.367 \\
(-0.34) \\
\end{array}$ \\
\hline INVCYCLE & $\begin{array}{l}-1.999 \\
(-1.09) \\
\end{array}$ & $\begin{array}{l}-2.055 \\
(-1.12) \\
\end{array}$ & $\begin{array}{l}-2.071 \\
(-1.12) \\
\end{array}$ \\
\hline AGE & $\begin{array}{l}-0.001 \\
(-1.03) \\
\end{array}$ & $\begin{array}{l}-0.001 \\
(-1.02) \\
\end{array}$ & $\begin{array}{l}-0.001 \\
(-1.05) \\
\end{array}$ \\
\hline LIQUIDITY & $\begin{array}{l}0.042 \\
(1.04)\end{array}$ & $\begin{array}{l}0.042 \\
(1.03)\end{array}$ & $\begin{array}{l}0.042 \\
(1.03)\end{array}$ \\
\hline Year dummy & Included & Included & Included \\
\hline Ind. dummy & Included & Included & Included \\
\hline Observations & 4,224 & 4,224 & 4,224 \\
\hline Adj. R2 & 0.610 & 0.610 & 0.610 \\
\hline
\end{tabular}




\subsection{Monitoring of Real Activities Manipulation}

Table 5 reports the empirical results of testing an individual blockholder's influence on real activities manipulations. In Table 5, abnormal cash flow from operation (ABCFO) has no systematic relationship with the individual blockholders. This result is reasonable because cash flow from operation, not accrual-based performance measures like revenue or income, is the ultimate goal of the operation. Therefore, the costs of sacrificing cash from operation are likely to be larger than the benefit of overstating revenue. Especially, individual blockholder's limited voting power makes the benefit of overstating revenue much smaller than the costs of sacrificing cash flows. In sum, the nonexistence of systematic relation between DUMMY INDIV and ABCFO is not surprising.

Table 5: Real Activities Manipulations: Abnormal Operating Cash Flows

\begin{tabular}{|c|c|c|c|}
\hline Variables & $\begin{array}{c}\text { (1) } \\
\text { Full sample } \\
\text { ABCFO }\end{array}$ & $\begin{array}{c}(2) \\
A B C F O>0 \\
A B C F O\end{array}$ & $\begin{array}{c}(3) \\
\text { ABCFO }<0 \\
\text { ABCFO }\end{array}$ \\
\hline DUMMY INDIV $_{\text {IN }}$ & $\begin{array}{l}0.002 \\
(0.31) \\
\end{array}$ & $\begin{array}{l}0.008 \\
(1.26) \\
\end{array}$ & $\begin{array}{l}0.003 \\
(0.52) \\
\end{array}$ \\
\hline NUMBER $_{\text {INDIV }}$ & $\begin{array}{l}-0.002 \\
(-0.41)\end{array}$ & $\begin{array}{l}-0.004 \\
(-1.52)\end{array}$ & $\begin{array}{l}-0.001 \\
(-0.29)\end{array}$ \\
\hline OWN $N_{\text {CTRL }}$ & $\begin{array}{l}0.003 \\
(0.46)\end{array}$ & $\begin{array}{l}0.003 \\
(0.61)\end{array}$ & $\begin{array}{l}-0.006 \\
(-1.02)\end{array}$ \\
\hline $\mathrm{OWN}_{\mathrm{FOR}}$ & $\begin{array}{l}0.017^{*} \\
(1.91)\end{array}$ & $\begin{array}{l}0.010 \\
(1.23)\end{array}$ & $\begin{array}{l}0.007 \\
(0.84)\end{array}$ \\
\hline SIZE & $\begin{array}{c}0.004^{* * *} \\
(3.60)\end{array}$ & $\begin{array}{l}-0.001 \\
(-1.47)\end{array}$ & $\begin{array}{c}0.004^{* * *} \\
(3.22)\end{array}$ \\
\hline LEV & $\begin{array}{c}-0.028^{\star \star *} \\
(-6.96)\end{array}$ & $\begin{array}{l}-0.006 \\
(-1.52)\end{array}$ & $\begin{array}{c}-0.011^{\star \star \star} \\
(-3.03)\end{array}$ \\
\hline ROA & $\begin{array}{c}0.322^{\star \star \star} \\
(13.78)\end{array}$ & $\begin{array}{c}0.184^{\star * \star} \\
(7.84) \\
\end{array}$ & $\begin{array}{c}0.100^{\star \star \star *} \\
(4.76)\end{array}$ \\
\hline LAG_ROA & $\begin{array}{c}0.067^{\star \star *} \\
(2.75)\end{array}$ & $\begin{array}{c}0.047^{\star *} \\
(2.11)\end{array}$ & $\begin{array}{l}0.016 \\
(0.77) \\
\end{array}$ \\
\hline MTB & $\begin{array}{c}0.006^{\star * \star} \\
(2.87)\end{array}$ & $\begin{array}{c}0.005^{\star \star \star} \\
(2.73)\end{array}$ & $\begin{array}{l}-0.003 \\
(-1.59) \\
\end{array}$ \\
\hline LAG_ACC & $\begin{array}{l}-0.037^{\star \star} \\
(-2.06)\end{array}$ & $\begin{array}{c}-0.039^{\star \star \star} \\
(-2.60)\end{array}$ & $\begin{array}{l}-0.005 \\
(-0.35)\end{array}$ \\
\hline Year dummy & Included & Included & Included \\
\hline Ind. dummy & Included & Included & Included \\
\hline Observations & 4,224 & 2,341 & 1,883 \\
\hline Adj. R2 & 0.184 & 0.156 & 0.079 \\
\hline
\end{tabular}

Firm-clustered t-values are presented in parentheses. * ${ }^{* *}$, and *** indicate statistical significance at $10 \%, 5 \%$, and $1 \%$ in a twotailed test, respectively.

As shown in column (1) of Table 6, ABPROD is positively related with DUMMY INDIV $_{\text {, implying that firms }}$ with individual blockholders are likely to overproduce. This result implies that firms with individual blockholders use overproduction to inflate financial outcome. Real activities manipulation is an alternative method for accruals manipulation on income management (Cohen, Dey, \& Lys, 2008). Tables 2 and 3 show that an individual blockholder increases the use of income-decreasing accruals, implying that individual blockholder's presence increases the cost of accruals manipulation; hence, real activities manipulation could replace accruals manipulation. The results of Table 6 support this conjecture.

Columns (2) and (3) show that the effect of individual blockholder on abnormal production varies depending on the sign of abnormal production. Without earnings management, if other conditions are equal, predicting future weak sales results in underproduction. In other words, underproduction could be a sign that managers of the firm have a negative opinion about the firm's future operation. Therefore, controlling shareholders can utilize overproduction for both overstating earnings and concealing weak production to prevent individual blockholders' intervention. This explains why DUMMY ${ }_{\text {INDIV }}$ is significant only in column (3).

Table 6: Real Activities Manipulations: Abnormal Production

\begin{tabular}{|c|c|c|c|}
\hline Variables & $\begin{array}{c}\text { (1) } \\
\text { Full sample } \\
\text { ABPROD }\end{array}$ & $\begin{array}{c}(2) \\
\text { ABPROD > } 0 \\
\text { ABPROD }\end{array}$ & $\begin{array}{c}(3) \\
\text { ABPROD }<0 \\
\text { ABPROD }\end{array}$ \\
\hline DUMMY INDIV $_{\text {IN }}$ & $\begin{array}{l}0.022^{*} \\
(1.70) \\
\end{array}$ & $\begin{array}{l}0.008 \\
(0.56) \\
\end{array}$ & $\begin{array}{c}0.036^{\star * \star} \\
(2.99) \\
\end{array}$ \\
\hline NUMBER $_{\text {INDIV }}$ & $\begin{array}{c}-0.017^{\star *} \\
(-2.23)\end{array}$ & $\begin{array}{l}-0.013 \\
(-1.50)\end{array}$ & $\begin{array}{c}-0.018^{\star \star} \\
(-2.32)\end{array}$ \\
\hline $\mathrm{OWN}_{\mathrm{CTRL}}$ & $\begin{array}{l}-0.005 \\
(-0.22) \\
\end{array}$ & $\begin{array}{l}0.015 \\
(1.29) \\
\end{array}$ & $\begin{array}{l}0.018 \\
(1.14)\end{array}$ \\
\hline $\mathrm{OWN}_{\mathrm{FOR}}$ & $\begin{array}{l}-0.015 \\
(-0.61)\end{array}$ & $\begin{array}{l}0.012 \\
(0.77)\end{array}$ & $\begin{array}{l}-0.004 \\
(-0.23)\end{array}$ \\
\hline SIZE & $\begin{array}{l}-0.000 \\
(-0.06)\end{array}$ & $\begin{array}{l}0.000 \\
(0.00)\end{array}$ & $\begin{array}{l}0.001 \\
(0.28)\end{array}$ \\
\hline LEV & $\begin{array}{l}0.007 \\
(0.71) \\
\end{array}$ & $\begin{array}{c}0.012^{\star *} \\
(1.99) \\
\end{array}$ & $\begin{array}{l}0.003 \\
(0.32) \\
\end{array}$ \\
\hline $\mathrm{ROA}$ & $\begin{array}{c}-0.403^{* * *} \\
(-10.23) \\
\end{array}$ & $\begin{array}{c}-0.152^{* * *} \\
(-5.11) \\
\end{array}$ & $\begin{array}{c}-0.246^{* \star *} \\
(-6.41)\end{array}$ \\
\hline LAG_ROA & $\begin{array}{l}-0.023 \\
(-0.61)\end{array}$ & $\begin{array}{l}0.033 \\
(1.14)\end{array}$ & $\begin{array}{l}0.026 \\
(0.80)\end{array}$ \\
\hline MTB & $\begin{array}{c}-0.019^{* * *} \\
(-3.51)\end{array}$ & $\begin{array}{l}0.002 \\
(0.44) \\
\end{array}$ & $\begin{array}{c}-0.017^{\star * *} \\
(-4.01)\end{array}$ \\
\hline LAG_ACC & $\begin{array}{l}0.029 \\
(1.19)\end{array}$ & $\begin{array}{l}-0.025 \\
(-1.47)\end{array}$ & $\begin{array}{l}0.008 \\
(0.31)\end{array}$ \\
\hline Year dummy & Included & Included & Included \\
\hline Ind. dummy & Included & Included & Included \\
\hline Observations & 4,224 & 2,179 & 2,045 \\
\hline Adj. R2 & 0.129 & 0.138 & 0.202 \\
\hline
\end{tabular}

Firm-clustered t-values are presented in parentheses. ${ }^{*},{ }^{* *}$, and ${ }^{* * *}$ indicate statistical significance at $10 \%, 5 \%$, and $1 \%$ in a twotailed test, respectively.

Table 7 presents the influence of an individual blockholder on abnormal discretionary expenses (ABDISX). Discretionary expenses are also influenced by individual blockholders, although the effect is limited to subsample with negative abnormal discretionary expenses. Table 6 shows that a firm with individual blockholders reduces abnormal expenses more than a firm without individual blockholders. The main components of discretionary expenses are research and development (R\&D), advertising, and selling expenses. These expenses increase as the activity of firm operation increases. Thus, negative abnormal discretionary expenses are a sign that the firm is struggling in the product market. Although reducing $R \& D$ or advertising expenses could aggravate the situation, the firm 
is expected to reduce discretionary expenses because the controlling shareholder has the incentive to avoid individual blockholders' disciplinary actions. This explains why the negative coefficient of DUMMY INDIV is found only in subsamples having negative abnormal discretionary expenses.

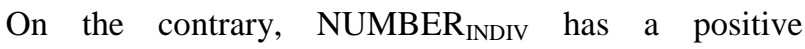
coefficient in column (3), indicating that the costs of the reduction of discretionary expenses increase as the number of individual blockholders increases. As previously explained, the monitoring of individual blockholder becomes stronger as the number of individual blockholders increases.

Table 7: Real Activities Manipulations: Abnormal Discretionary Expenses

\begin{tabular}{|c|c|c|c|}
\hline Variables & $\begin{array}{c}\text { (1) } \\
\text { Full sample } \\
\text { ABDISX }\end{array}$ & $\begin{array}{c}\text { (2) } \\
\text { ABDISX >0 } \\
\text { ABDISX }\end{array}$ & $\begin{array}{c}\text { (3) } \\
\text { ABDISX }<0 \\
\text { ABDISX }\end{array}$ \\
\hline DUMMY INDIV $_{\text {IN }}$ & $\begin{array}{l}-0.002 \\
(-0.22)\end{array}$ & $\begin{array}{l}-0.003 \\
(-0.32)\end{array}$ & $\begin{array}{c}-0.008^{*} \\
(-1.94)\end{array}$ \\
\hline NUMBER INDIV & $\begin{array}{l}0.003 \\
(0.59)\end{array}$ & $\begin{array}{l}0.003 \\
(0.56)\end{array}$ & $\begin{array}{c}0.006^{\star \star} \\
(2.46)\end{array}$ \\
\hline $\mathrm{OWN}_{\mathrm{CTRL}}$ & $\begin{array}{l}0.007 \\
(0.55)\end{array}$ & $\begin{array}{l}-0.004 \\
(-0.21)\end{array}$ & $\begin{array}{l}0.005 \\
(0.84)\end{array}$ \\
\hline $\mathrm{OWN}_{\mathrm{FOR}}$ & $\begin{array}{l}0.001 \\
(0.07)\end{array}$ & $\begin{array}{l}-0.011 \\
(-0.47)\end{array}$ & $\begin{array}{l}-0.005 \\
(-0.77)\end{array}$ \\
\hline SIZE & $\begin{array}{l}0.003 \\
(1.43)\end{array}$ & $\begin{array}{l}0.004 \\
(1.53)\end{array}$ & $\begin{array}{l}0.001 \\
(0.90)\end{array}$ \\
\hline LEV & $\begin{array}{l}0.006 \\
(0.92) \\
\end{array}$ & $\begin{array}{l}-0.010 \\
(-1.26) \\
\end{array}$ & $\begin{array}{l}0.000 \\
(0.16)\end{array}$ \\
\hline $\mathrm{ROA}$ & $\begin{array}{l}0.013 \\
(0.56) \\
\end{array}$ & $\begin{array}{c}-0.058^{* *} \\
(-1.99)\end{array}$ & $\begin{array}{l}-0.001 \\
(-0.11)\end{array}$ \\
\hline LAG_ROA & $\begin{array}{l}-0.033 \\
(-1.31)\end{array}$ & $\begin{array}{l}0.001 \\
(0.02)\end{array}$ & $\begin{array}{l}-0.020^{*} \\
(-1.67)\end{array}$ \\
\hline MTB & $\begin{array}{c}0.013^{\star \star \star} \\
(3.74)\end{array}$ & $\begin{array}{c}0.007^{\star *} \\
(2.07)\end{array}$ & $\begin{array}{l}0.003^{*} \\
(1.95)\end{array}$ \\
\hline LAG_ACC & $\begin{array}{l}-0.019 \\
(-1.35) \\
\end{array}$ & $\begin{array}{l}-0.025 \\
(-1.27) \\
\end{array}$ & $\begin{array}{l}0.002 \\
(0.31) \\
\end{array}$ \\
\hline Year dummy & Included & Included & Included \\
\hline Ind. dummy & Included & Included & Included \\
\hline Observations & 4,224 & 1,547 & 2,677 \\
\hline Adj. R2 & 0.081 & 0.268 & 0.324 \\
\hline
\end{tabular}

\subsection{Loss Avoidance}

Table 8 reports the influence of an individual blockholder on loss avoidance. The dependent variable is a dummy variable; hence, Probit regression is used. All three proxies for individual blockholder have positive coefficients, although the coefficient of DUMMYINDIV is statistically insignificant. The positive relation indicates that individual blockholders increase the tendency of loss avoidance. This result is intuitive because reporting loss would incur consequences that are costly to controlling shareholders (Burgstahler \& Dichev, 1997; Edmans, 2014). Thus, the presence or influence of individual blockholders strengthens the firm's loss avoidance.
Table 8: Loss Avoidance

\begin{tabular}{|c|c|c|c|}
\hline Variables & $\begin{array}{c}(1) \\
\text { LAVOID }\end{array}$ & $\begin{array}{c}(2) \\
\text { LAVOID } \\
\end{array}$ & $\begin{array}{c}(3) \\
\text { LAVOID }\end{array}$ \\
\hline DUMMYINDIV & $\begin{array}{l}0.220 \\
(1.51)\end{array}$ & & \\
\hline NUMBER $R_{\text {INDIV }}$ & & $\begin{array}{c}0.206^{* *} \\
(2.28)\end{array}$ & \\
\hline $\mathrm{OWN}_{\text {INDIV }}$ & & & $\begin{array}{c}2.009^{* *} \\
(2.18)\end{array}$ \\
\hline$O W N_{C T R L}$ & $\begin{array}{l}-0.419 \\
(-1.46) \\
\end{array}$ & $\begin{array}{l}-0.378 \\
(-1.31) \\
\end{array}$ & $\begin{array}{l}-0.390 \\
(-1.36)\end{array}$ \\
\hline$O W N_{\mathrm{FOR}}$ & $\begin{array}{c}-1.309^{\star \star \star} \\
(-2.66)\end{array}$ & $\begin{array}{c}-1.298^{\star \star \star} \\
(-2.65)\end{array}$ & $\begin{array}{c}-1.286^{\star \star \star} \\
(-2.63)\end{array}$ \\
\hline MTB & $\begin{array}{c}0.293^{\star \star \star} \\
(3.91)\end{array}$ & $\begin{array}{c}0.299^{\star \star \star} \\
(4.00)\end{array}$ & $\begin{array}{c}0.297^{\star \star \star} \\
(3.98)\end{array}$ \\
\hline SIZE & $\begin{array}{c}0.121^{\star *} \\
(2.32)\end{array}$ & $\begin{array}{c}0.123^{\star *} \\
(2.37)\end{array}$ & $\begin{array}{c}0.121^{\star *} \\
(2.35)\end{array}$ \\
\hline BIGN & $\begin{array}{l}0.053 \\
(0.45) \\
\end{array}$ & $\begin{array}{l}0.044 \\
(0.38) \\
\end{array}$ & $\begin{array}{l}0.043 \\
(0.37) \\
\end{array}$ \\
\hline CFO & $\begin{array}{c}-2.906^{* * *} \\
(-3.53)\end{array}$ & $\begin{array}{c}-2.913^{\star * *} \\
(-3.52) \\
\end{array}$ & $\begin{array}{c}-2.899^{\star * *} \\
(-3.49) \\
\end{array}$ \\
\hline DUMMY $_{\text {FIN }}$ & $\begin{array}{c}-0.236^{*} \\
(-1.76)\end{array}$ & $\begin{array}{c}-0.244^{*} \\
(-1.83) \\
\end{array}$ & $\begin{array}{c}-0.243^{*} \\
(-1.82) \\
\end{array}$ \\
\hline $\mathrm{ROA}$ & $\begin{array}{c}-4.126^{* \star *} \\
(-5.71)\end{array}$ & $\begin{array}{c}-4.158^{\star * \star} \\
(-5.72)\end{array}$ & $\begin{array}{c}-4.128^{\star * *} \\
(-5.68)\end{array}$ \\
\hline YRET & $\begin{array}{l}-0.159 \\
(-0.99) \\
\end{array}$ & $\begin{array}{l}-0.158 \\
(-0.99) \\
\end{array}$ & $\begin{array}{l}-0.160 \\
(-1.00)\end{array}$ \\
\hline Year dummy & Included & Included & Included \\
\hline Ind. dummy & Included & Included & Included \\
\hline Observations & 4,142 & 4,142 & 4,142 \\
\hline Adj. R2 & 0.1515 & 0.1534 & 0.1528 \\
\hline
\end{tabular}

\section{Conclusion}

This study investigates whether or not Korean individual blockholders provide monitoring of accounting information. I find that individual blockholders increase accounting conservatism and suppress accruals overstatement. However, the presence of individual blockholders enhances loss avoidance and real activities manipulation. These results imply that an individual blockholder can be an effective corporate governance mechanism; however, the influence has limit.

This paper is the first to report Korean individual blockholders' corporate governance role on financial reporting. This is the main contribution of this paper. However, this study has limitations as well. This study does not address personal characters of individual blockholders, for example, investment horizon and expertise, which could affect monitoring efficiency. In addition, the hand-collected data may have measurement errors. I rely on publicly available information; therefore, information hidden from the public is not considered, which could incur measurement error.

This study descriptively reports the relation between an individual blockholder and accounting quality using regression analysis. However, the regression analysis cannot 
show detailed channels through which an individual investor influences the accounting information. The channels should be investigated by using other research methods.

\section{References}

Agrawal, A., \& S. Chadha. (2005). Corporate governance and accounting scandals. The Journal of Law and Economics, 48(2), 371-406.

Baek, J.-S., Kang, J.-K., \& Lee, I. (2006). Business groups and tunneling: Evidence from private securities offerings by Korean Chaebols. The Journal of Finance, 61(5), 2415-2449.

Burgstahler, D., \& Dichev. I. (1997). Earnings management to avoid earnings decreases and losses. Journal of Accounting and Economics, 24(1), 99-126.

Bushee, B. J. (1998). The influence of institutional investors on myopic R\&D investment behavior. Accounting Review, 73(3), 305-333.

Claessens, S., Djankov, S., \& Lang, L. H. P. (2000). The separation of ownership and control in East Asian corporations. Journal of Financial Economics, 58(1-2), 81-112.

Cohen, D. A., Dey, A., \& Lys, T. Z. (2008). Real and accrual-based earnings management in the pre- and postSarbanes-Oxley periods. The Accounting Review, 83(3), 757-787.

Dou, Y., Hope, O.-K., Thomas, W. B., \& Zou., Y. (2016). Individual large shareholders, earnings management, and capital-market consequences. Journal of Business Finance \& Accounting, 43(7-8), 872-902.

Edmans, A. (2014). Blockholders and corporate governance. Annual Review of Financial Economics, 6(1), 23-50.

Faccio, M. (2006). Politically connected firms. The American Economic Review, 96(1), 369-386.

Farber, D. B. (2005). Restoring trust after fraud: Does corporate governance matter? The Accounting Review, 80(2), 539-561.

Han, S.-H., Kang, K., \& Shin, Y. S. (2016). Bond ratings, corporate governance, and cost of debt: The case of Korea. The Journal of Asian Finance, Economics and Business, 3(3), 5-15.

Healy, P. M., \& Wahlen, J. M. (1999). A review of the earnings management literature and its implications for standard setting. Accounting Horizons, 13(4), 365-383.

Kang, S.-A., \& Kim, T.-J. (2014). A study of the relationship between corporate governance and real earnings management: Based on foreign investors and growth. Journal of Distribution Science, 12(4), 85-92.

Khan, M., \& Watts, R. L. (2009). Estimation and empirical properties of a firm-year measure of accounting conservatism. Journal of Accounting and Economics, $48(2-3), 132-150$.

Kothari, S. P., Leone, A. J., \& Wasley, C. E. (2005). Performance matched discretionary accrual measures. Journal of Accounting \& Economics, 39(1), 163-197.

La Porta, R., Lopez-de-Silanes, F., Shleifer, A., \& Vishny, R. W. (2000). Investor protection and corporate governance. Journal of Financial Economics, 58(1-2), 3-27.

Larcker, D. F., Richardson, S. A., \& Tuna, I. (2007). Corporate governance, accounting outcomes, and organizational performance. The Accounting Review, 82(4), 963-1008.

Lee, W. J. (2018). Group-affiliated firms and corporate social responsibility activities. The Journal of Asian Finance, Economics and Business, 5(4), 127-133.

Petersen, M. A. (2009). Estimating standard errors in finance panel data sets: Comparing approaches. Review of Financial Studies, 22(1), 435-480.

Roychowdhury, S. (2006). Earnings management through real activities manipulation. Journal of Accounting and Economics, 42(3), 335-370.

Salehi, M., Abedini, B., \& Bahrani, R. (2014). The Relationship between ownership structure and conservatism of companies in Iran. Journal of Distribution Science, 12(5), 27-32.

Salehi, M., \& Asgari, A. (2013). Corporate governance and earnings quality: The Iranian evidence. Journal of Distribution Science, 11(6), 5-11.

Shleifer, A., \& Vishny, R. W. (1997). A survey of corporate governance. The Journal of Finance, 52(2), 737-783.

Vijayakumaran, S., \& Vijayakumaran, R. (2019). Corporate governance and capital structure decisions: Evidence from Chinese listed companies. The Journal of Asian Finance, Economics and Business, 6(3), 67-79.

Watts, R. L. (2003). Conservatism in accounting Part I: Explanations and implications. Accounting Horizons, 17(3), 207-221. 